\title{
When the Body Speaks (to) the Political: Feminist Activism in Latin America and the Quest for Alternative Democratic Futures
}

\section{Natália Maria Félix de Souza*}

\begin{abstract}
The article claims that the feminist movements emerging in the context of contemporary Latin American political struggles - such as Ni Una Menos - allow for a re-conceptualisation of the political, along with its subjects and objects. The uniqueness of these movements is predicated on the way they managed to link the ordinary killings of women's bodies to the extraordinary alliances between different social movements. A closer inspection into these ongoing experiences that mobilise different, rhizomatic arenas of political entanglements - such as the internet and the streets allows us to see how Latin American feminist attachments and movements can redefine democratic practices and build different forms of community. By resisting what is perceived as 'a war against women in Latin America, these movements allow for understanding the operation of a gendered necropolitics, which ties women's death with the ultimate functioning of modern politics and modern subjectivities. In doing so, they politicise not only the lives (and therefore voices) of women who are struggling in/for the political, but also the deaths (and therefore silences) on which the political has been built. Furthermore, by politicising the role of the body in the political and ethical arena, these movements open our political imaginaries to the possibilities of new attachments, filiations and articulations that are not subsumed under abstract universal categories and values, nor limited to identitarian and thus legalistic affirmations of the political. Following these arguments, I argue that contemporary feminist articulations in Latin America productively dispute the validity of the abstract, universal, modern 'human' to think alternative political futures. By politicising materiality and embodiment alongside language and discourse as productive of political ontologies, feminists open the space for reclaiming the political function of the female body.
\end{abstract}

Keywords: Latin America; body; feminism; democratic politics; political resistance; femicide.

Pontifícia Universidade Católica de São Paulo (PUC-SP), São Paulo-SP, Brazil; nataliamfsouza@gmail.com. ORCID iD 0000-0001-9914-8985. 


\section{Introduction}

The impressive and fast articulation of an International Women's Strike on 8 March 2017 called attention to the particularly popular character of contemporary feminist movements, which have been characterised as a 'feminism of the 99\%' (Topping and Redden 2017; Alcoff et al 2017; Arruzza and Bhattacharya 2017a). In calling forth the strike, a letter published by broadly known feminists (Alcoff et al 2017) declared to derive its inspiration from the Argentinian movement $\mathrm{Ni}$ Una Menos (Not One Less), which achieved a historical articulation of women against femicide and male violence after the discovery of Chiara Paez's body buried in the house of her boyfriend, on 11 May 2015. Despite the crude nature of the crime, Chiara's murder is one drop in a sea of similar cases throughout Argentina - and Latin America more generally (Pan American Health Organization 2012, 2015; Pomeraniec 2015).

The recent trajectory of the protests that followed calls attention to the importance feminist movements in Latin America have achieved in the past few years. According to Veronica Gago (2017), it is noteworthy that feminism, once considered a minority position which summoned much suspicion, has now become able to '[make] diversity a strength rather than weakness', thus allowing for the emergence of a 'feminism of the masses.' An unshakable ambiguity has however marked this movement, whose growth is paralleled only to the highest rates of violence and brutality against women throughout Latin America. ${ }^{1}$ For Gago, this ambiguity ensues precisely from the popular character of these movements, which are no longer guided by 'academic, elitist, or just plain corporate' interests, but emanate from the streets, from those directly affected by the 'new wars against women's bodies' in Latin America (Segato 2014a, 2014b).

These developments in feminist articulations introduce new nuances in the political practices in the region. Increasingly, feminists are seen not only as identity groups representing a minority position within a larger and more important movement against capital and oppression, but as occupying the forefront of the political arena - which has been harnessing renewed waves of anger and sympathy. In this sense, feminist articulations in Latin America have become a productive site to look for ways of rearticulating resistance within a scenario particularly repellent to the development of progressive political agendas (Gago and Sztulwark 2016). ${ }^{2}$ Despite the multiplicity of layers that compose this scenario, it is undeniable that women have come to occupy an irrepressible space within the multiple resistance movements we are witnessing, characterising what Conway (2012, 2018) called a shift in feminist solidarities from a primarily intra-movement articulation among feminist and women's groups to an inter-movement building of solidarities also directed to non-feminist movements and collectives.

Following the trail of these recent forms of organization, I want to argue that a re-articulation of political resistance and therefore of the entire political framework is under way through feminist articulations in Latin America. Particularly, I am interested in how these movements have been appealing to the female body and, in many ways, to the materiality of the dead female body to build resistance. In this scenario, appeals to the suffering and pain of such bodies have been serving to regroup rather than galvanise feminist 
solidarities and attachments, which have for some time remained oppositional due to a certain politics of identity, unable to recognise the role of feminism beyond the state and the state institutions. In a sense, the growing appearance of the violated female body, rather than multiply the grievances within feminist attachments has been offering the opportunity to re-articulate feminist resistance in the face of a crisis of democratic politics.

Discussions over materiality and embodiment have been at the centre of feminist scholarship for some time now. Claiming back the situatedness and positionality of bodies has allowed feminists to defy the mind/body dualism that structures most of Western philosophy and retrieve the centrality of questions of gender, sexuality, race, class, ethnicity, nationality and so on to the structuring of the political. Reflecting over these feminist contributions about materiality, the article sheds light on the importance of claiming back the body - living, dead, surviving (Dauphinée and Masters 2007) - for recent feminist articulations throughout Latin America. In this context, bodies have increasingly emerged as catalysts of renewed feminist discourses and practices in the region. As I will argue, this discursive and visual intrusion of the body into the political arena has the potential to open avenues to re-signify our political practices and forms of resistance.

In what follows, I claim that feminist movements emerging in the context of contemporary Latin American political struggles - such as Ni Una Menos - allow for a re-conceptualisation of the political, along with its subjects and objects. The uniqueness of these movements is predicated on the way they managed to forge a link between the ordinary killings of women's bodies to the extraordinary alliances between different social movements. A closer inspection into these ongoing experiences that mobilise different, rhizomatic arenas of political entanglements - such as the Internet and the streets - allows us to see how Latin American feminist attachments and movements can be redefining democratic practices and building different forms of community.

By resisting what is perceived as 'a war against women in Latin America,' these movements allow for understanding the operation of a gendered necropolitics, which ties women's death to the ultimate functioning of modern politics and modern subjectivities. In doing so, they politicise not only the lives (and therefore voices) of women who are struggling in/for the political, but also the deaths (and therefore silences) on which the political has been built. Furthermore, by politicising the role of the body in the political and ethical arena, these movements open our political imaginaries to the possibilities of new attachments, filiations and articulations that are not subsumed under abstract universal categories and values, nor limited to identitarian and thus legalistic affirmations of the political.

In order to construct this argument, I build upon Rita Laura Segato's diagnosis of gendered violence in Latin America, which offers a very historical and contextual approach to the ways women's bodies have been at the centre of colonial modernity in the region. Far from being the result of personal tragedies, Segato shows how the growing violence against feminized bodies have become the epicentre of a war through which Latin American patriarchal, modern-colonial societies try to retrieve some form of sovereignty over their territories - being therefore an expressive form of violence which tells us much about the relations between coloniality and gender in the region. 
Trying to reflect about the role of the Third World feminist intellectual activist in this scenario, and therefore, to take account of our own responsibilities in the political processes going on in the region, the last part of the article supplements Segato's diagnosis with Gayatri Spivak's discussion over the importance of restoring political representation as part of our intellectual endeavours. Following her well-known quest for subaltern representation, I claim that feminist articulations spanning from Latin America have been productively building an 'infrastructure for agency' of the female body, opening important avenues for developing alternative 'habits of democratic behaviour' (Spivak 2006).

\section{Feminist articulations in Latin America}

On 19 October 2016, a major online articulation initiated by the Argentinian collective $\mathrm{Ni}$ Una Menos was able to mobilise a protest of national proportions against gender violence and the rampant number of femicides throughout the country (Goñi 2016; Cartolano 2016; Palmeiro 2017a). Marked by the hashtag \#MiércolesNegro (\#BlackWednesday), the protest was triggered by the brutal murder of 16-year-old Lucía Pérez, after being raped, tortured and abandoned in a hospital by her perpetrators, who alleged she was suffering from overdose (Infobae 2016; Vinte minutos 2016). ${ }^{3}$ The protest called for a one-hour strike from women working in every form of occupation, followed by a march through the streets of Buenos Aires. It was immediately replicated throughout different cities in Latin America (Gordon 2016).

On the occasion, a letter issued by the movement under the call \#NosotrasParamos (\#WeStrike) was signed by a large number of organisations - from grassroots collectives to anti-capitalist, unionist movements - demanding that male violence against women be connected to other forms of exploitation, from capitalist exploitation and precarisation of jobs to issues relating to gender violence and reproductive rights. The letter cut across the multiple grievances that characterised previous feminist groups, claiming to represent women in all positions:

We are the housewives, the workers of the formal and informal economy, the teachers, the cooperativists, the academics, the workers, the unemployed, the journalists, the militants, the artists, the mothers and the daughters, the domestic employees, those you cross by in the streets, those that leave the house, those that are in the neighborhood, those that went to a party, those that have a meeting, those that walk alone or accompanied, those that decide to abort, those that do not, those that decide on how and with whom to live our sexuality. We are women, trans, transvestites, lesbians. We are many and from the fear that they want to impose on us, and the fury from the way they take us by force of violence, we make a sound, a mobilisation, a common cry: Not One Less! We want us alive! ${ }^{4}(\mathrm{Ni}$ Una Menos 2016). 
Before Lucía, on 11 May 2015, the discovery of the body of 14-year-old Chiara Paez, pregnant and buried in the backyard of her boyfriend's house, had already spanned an articulation against femicide which, under the rallying cries of \#NiUnaMenos (\#NotOneLess) and \#VivasNosQueremos (\#WeWantUsAlive), signalled to a collective decision not to let these bodies be treated as objectified victims of personal tragedies anymore (Ni Una Menos 2017b). Instead, there was an increasing disposition not only to expose the exemplary, repetitive and therefore systematic character of violence against women, but also, and as a consequence, to rediscover female agency through the politicisation of the dead female bodies. According to Cecília Palmeiro (2017a), professor of Latin American Studies and Queer Theory and activist of the movement, femicides are only the tip of the iceberg of a system of violences affecting women. However, the powerful message that they send and the strong opinions that they nurture throughout the entire society was an important catalyst for the movement to reach public opinion.

The movement was soon joined by hundreds of thousands of people - from artists to politicians, women, men and children - and the march was able to receive a speedy response by Argentina’s Supreme Court (Pomeraniec 2015). ${ }^{5}$ This ability to mobilise street marches through the Internet was replicated in the organisation of the International Women's Strike on 8 March 2017, which now connected a wide web of feminist movements in multiple countries, characterising a strong transnational feminist articulation. Under the hashtag \#8M, the strike was convoked in repudiation of the different forms of gender violence, and was adhered to in more than 40 countries (Palmeiro 2017a; Arruzza and Bhattacharya 2017a). ${ }^{6}$

According to Arruzza and Bhattacharya (2017b), the strike becomes a particularly strong weapon for contemporary feminist articulations because of the way it helps to make visible all the work women do all the time - and for much of which they are not even paid. Different from a general strike, a women's strike highlights the unity between the home and the workplace, shedding light into particular forms of exploitation which remain invisible when the strike does not take account of the specific conditions which afflict women in capitalist societies.

The expansive agenda of the strike, which called for inclusiveness and connection between issues of class, gender, sexuality, ethnicity, and race, not only legitimizes the right to strike, but calls attention to the materiality of women's bodies and the need to reclaim women's rights over their bodies - both in the sense of retrieving female sexuality and desire from state control, but also in the sense of keeping women's bodies alive in the face of the advancing biopolitical/necropolitical regimes. With these demands in mind, the call issued by Ni Una Menos on 8 March emphasized not only the presence and voices of women struggling against violence, but also their absence, the voicelessness of all the absent bodies of women who had been biologically or socially killed by profoundly patriarchal regimes of power. Under the hashtag \#NoEstamosTodas (\#WeAreNotAll), the call states:

We strike because we are missing the victims of femicide, voices that are violently extinguished to the chilling rhythm of one per day only in 
Argentina. We are missing the murdered lesbians and transvestites. We are missing the political prisoners, the persecuted, the murdered in our Latin American territory for defending the land and its resources. We are missing women imprisoned for minor crimes that criminalise forms of survival, while the crimes of corporations and drug trafficking go unpunished because they benefit capital. We are missing the dead and those imprisoned for unsafe abortions. We are missing those disappeared by trafficking networks; the victims of sexual exploitation. In front of homes that have become hell, we organise to defend ourselves and take care of each other. In the face of sexist crime and its pedagogy of cruelty, in the face of the media's attempt to victimise and terrorise us, we make of individual mourning a collective consolation, and of rage a shared struggle. Faced with cruelty, more feminism (Ni Una Menos 2017a).

\section{Gendered necropolitics in Latin America}

For Rita Laura Segato, it has become urgent to understand the new forms of war under way in Latin America and how they particularly affect the bodies of women. The informal character of these new wars - wars without a particular end, practised by state and non-state actors alike - has codified a new form of territoriality no longer related to the familiar territory of the nation-state, but to the mobile network of bodies that are not fixable. In this political scenario, violence against women's bodies cannot be reduced to the category of private, sexual crimes (as 'crimes of passion') - which ultimately serves as a way to individualise women's experiences and remove them from public accountability. In light of this, she argues that femicides should be considered crimes of war - 'femigenocides' (Segato 2014a).

These new wars are directly intertwined with the biopolitical function of power, which marks contemporary forms of pastoral power, concerned with the government of subjectivities (Foucault 2000, 2008; Segato 2014a). The biopolitical concern with the production and administration of bodies and subjectivities brings forth a different territorial paradigm, in which the body of the population becomes the frame for the inscription of power. In this scenario, women's bodies become themselves the territory of this inscription, especially due to their historical association with nature. According to Segato (2014a: 23), the body of the woman is the frame or support on which the moral defeat of the enemy is written.

Because of the broad spectre of power being exercised under biopolitical regimes, Segato understands that violence against women cannot be dealt with exclusively from the perspective of identity politics. Reducing these forms of violence to minority issues - as the 'woman question,' for instance - is, for her, a way of flattening and emptying the political complexity which revolves around the problem of the body. It serves, in a sense, to depoliticise the entire question of colonial modernity and its impact on places such as 
Latin America. Segato's argument complicates the identitarian binary opposition between victims and perpetrators which marks the modern-colonial paradigm, for its insufficiency to account for the multiple forms of violence that afflict the female and feminised bodies in general.

According to the author, the female and feminised bodies - from children to queer, black, marginalised and colonised bodies - are representations of bodies under tutelage, and therefore, violence against them represents not only a personal, individual aggression, but stands for a manifestation of the moral, political and social failure of those responsible for protecting them. Thus, the paradigm of power created by colonial modernity makes the exercise of power over these bodies a means to assure sovereignty over the national territory. From its inception, then, violence against the colonised female body, even when it occurred in the domestic arena, was never simply private, but an expressive manifestation of a certain political imaginary of conquest, the means through which colonial modernity was created.

In Latin America, the transition from traditional political organisations to modern state structures was deeply tied to a certain organisation of patriarchy and the creation of the 'public sphere.' Supplementing a longstanding feminist analysis of the interconnection between the formation of the modern state and the invention of the public/private binary (Peterson 1992), Segato $(2012,2016)$ claims that the colonial state which replaced former communitarian 'village worlds' in Latin America introduced a binary gender structure that was deeply at odds with the duality which marked communitarian gender dynamics. This previous duality which organised the communitarian field was not itself devoid of hierarchies and power structures; however, there was a profound reciprocity between gender positions, in that 'people [could] move between the positions given as natures and transmute themselves', making the village world 'trans in many ways' (Segato 2016: 616). The public and the private spaces in such articulations are profoundly intertwined and equally important for the functioning of society.

The entrance of colonial modernity in these spaces brought about a universalist rhetoric that tried to subsume all existence under the One subject of rationality and politics, the only one entitled to public speech and participation. The introduction of colonial binarism meant that the other of the One - a 'feminine, non-white, colonial, marginal, underdeveloped, deficient' (Segato 2016: 617) other - could only exist as a minority, a being lacking 'ontological fullness and reduced to fulfilling the function of alter or other regarding the One as a representative and referent of totality' (Segato 2016: 618). This minoritised, marginalised other becomes the condition of possibility for the existence of the all-encompassing One - the 'Human.' This 'Human,' of course, is now a necessarily masculine, white, property-owning, literate figure, the sole subject of public speech.

The importance of Segato's critique is that it reintroduces the question of politics at the heart of feminist approaches, signalling to the need to recover pluralism, rather than accepting the binary, modern-colonial political discourse and its necessarily exclusionary, imperialistic, misogynistic, classist, and racist structure. In this sphere, minorities are fated to be 'others and anomalies of the One in the collective imagination' who, in order to 
speak the language of politics, 'must perform a kind of drag' (Segato 2016: 618). Opening the discussion over the meanings of democracy, Segato's argument points to the need to surpass the identitarian and legalistic approach that took centre stage of the feminist agenda at the aftermath of the Cold War, and build a feminist political resistance that no longer compartmentalises the 'woman question' (Segato 2012, 2016).

This claim sheds light into the historicity of the 1970s feminist movement, which basically introduced a call for bringing the domestic space of female speech inside the political sphere, as a way to recover women's capacity to speak publicly and be taken seriously. As important as this call was in terms of advancing a feminist agenda, it ultimately meant the inscription of women's lives and their bodies as objects of government, to be controlled and protected, without granting them the ability to speak back to the political, as active participants of their own inscription. ${ }^{7}$ Through this means, the state is seen as granting with one hand what it took away with the other: it creates laws to defend women from the violence to which they are exposed precisely because this very state has already destroyed the institutions and communitarian fabric that could keep them safe (Segato 2012: 110).

Siding with Segato's claim, I argue that, by taking up an intersectional anti-systemic resistance against capital, feminist struggles in Latin America are able to better re-signify the role of violence against women in this system, rupture the binary logic of victims and perpetrators which organises many identitarian struggles, and perhaps assume a new stance in representing women's bodies in the political. The recent feminist articulations through the Internet and the streets, connecting Latin American struggles among themselves as much as with feminist movements throughout the world, signal precisely the construction of a transnational articulation which no longer admits easy dualisms or the erasure of some claims in the name of others (Palmeiro 2017a; Conway 2018). Gender violence is being treated less and less as a relation between men and women, and more as a system of production of such relations, in which the increasing number of dead bodies has something to say back to the way political struggles have been carried out in the past.

The cruelty of these forms of violence - as seen in the case of Lucía Perez's impalement and the number of gang rapes across Latin American countries, ${ }^{8}$ as well as in the growing animosity of groups against 'gender ideology,' from sexual education to abortion regulations ${ }^{10}$ - calls attention to what Segato $(2014 \mathrm{~b})$ termed the psychopathic pedagogy of cruelty which is nurtured by modern capitalism. In many ways, structural violences against women, whether they happen inside the household or - as current trends show ${ }^{11}$ - as direct fruits of the informal wars being conducted throughout Latin America, are less about personal manifestations of aggressive sexualities and more expressive of the attempt to recover a certain territorial sovereignty lost through modern capitalist oppression and emasculation.

The recognition of this trend can be seen in the call Ni Una Menos issued for the 2016 Women Strike:

We stop against femicides, which are the highest point of a plot of violence, which ties exploitation, cruelties and hatred against the most diverse forms of feminine autonomy and vitality; which thinks of 
our bodies as things to be used and discarded, to break and plunder. The rape and femicide of Lucía Pérez shows a sustained trend against women's autonomy and capacity for decision, action, choice and desire. [...] Like all femicides, Lucía's also points to the disciplinarisation of women and of all the people who rebel against the roles that this society sustains at full speed: you will be what is supposed to be normal or you will be nothing. And you cannot say NO because the cost of saying NO will be, in the end, death. From one captivity to another. From one type of exploitation to other, bloodier ones $(\mathrm{Ni}$ Una Menos 2016 [emphasis added]).

This expressiveness of violence against women's bodies helps to explain the apparent contradiction which accompanies the advancement of the feminist agenda in Latin America, where the growing political achievements do little to stop - or even reduce - violence against women. ${ }^{12}$ The very functioning of the system seems to depend on keeping women where they are: as docile bodies, victims of sexual predators that can only act inside the parameters of law - much as with the various other 'minorities.'

Confronted by these developments, it is possible to argue that there is a gendered necropolitics in place (Wright 2011; Aguilera 2017), which is at the basis of the re-articulation of female political resistance in Latin America. Mbembe's argument (2003) sheds light on the darker side of the biopolitical regimes which operate throughout the world, particularly in colonised spaces where racialised - and gendered - lives are more directly governed by a politics which operates through 'the work of death' than through a biopolitical production of life. Or better still, it points precisely to the way in which the production of (normative) life in some places gives way to the daily reproduction of (non-normative) dead bodies as the normalised condition. By stressing how the biopolitical and the necropolitical work in tandem, Mbembe (2003) calls attention to the need to politicise death, and understand how it can become the main signifier of the political. Where gendered and racial identification becomes the condition for the acceptability of death in biopolitical regimes, the reproduction of the human makes the 'sovereign right to kill' a nomological - rather than exceptional - condition of democracy.

In what remains of this article, we follow the claim that contemporary feminist articulations in Latin America, by working through intersectionality and making diversity a source of resistance, begins to touch precisely on the issue of bringing 'the woman question' to the heart of this necropolitical regime which operates not privately, but through the systematic reproduction of feminised, racialised, minoritised, marginalised, imperialised dead - or killable - bodies. If the state and the political are themselves predicated on the reproduction of death, politicising these (potentially dead) bodies becomes a way to re-articulate political resistance beyond the state apparatuses. Putting the female body in the centre of the analysis allows it to leave the position of an object-victim to be governed and protected by a patriarchal state structure, and instead to make a performatic intrusion into the public as a voice which speaks back and disrupts familiar claims about the political. 


\section{The question of materiality in feminist scholarship}

How do we grieve in a biopolitics whose primary activity is to remove that body from view? (Dauphinée and Masters 2007: xvi).

The body has long been considered a marginal matter in political philosophy. At most, bodies have circulated and been thought about as objects to be managed within our political theories and practices. Much of this condition derives from modern accounts of subjectivity which have more often than not pleaded for a disembodied self, a pure form of rationality able to strip itself from all forms of attachment in order to be able to produce critical, reliable knowledge about the world, as well as adequate policies to organise, govern and secure the individual and collective bodies that populate this world.

Pushing for a transformation of how modern politics has been thought about and practised over the last centuries, feminist approaches have long confronted what is seen as an ultimately misguided - patriarchal, imperialistic and oppressive - account of politics and science, and have claimed instead for the need to contemplate the materiality of bodies - their sexed and gendered realities - as a way not only to produce more reliable knowledge about politics, but above all to produce change and transformation for 'the embodied others, who are not allowed not to have a body' (Haraway 1991: 183). In politicising the materiality of bodies, feminists have been adamant in their opposition to the singularised category of 'Human, of a single subject position imbued with rationality, that could claim to offer a 'view-from-nowhere' - a neutral account of how the (singular) world works and therefore of who are its subjects and how they should relate to one another in the political arena.

By politicising the female body - the norms, images, symbols and discourses that circulate about and produce it, the structural and physical violence which afflicts it, the emotions and affects that mark it, the numerous forms through which power affects and differentiates the experience of the sexed body - feminism has been able to denaturalise both the assumption of universalism - i.e., of a universal form of rationality and subjectivity inhabiting the world - and the account of politics from which women were naturally excluded, or included as objects to be secured, cared for, protected. ${ }^{13}$

Donna Haraway's claim for a 'politics of location,' Judith Butler's notion of 'performativity', and Karen Barad's account of 'intra-activity' offer constructive approaches to understand the role of materiality within a reframing of the political. In all of their accounts, we see attempts to shatter the narcissistic view of the Cartesian subject, problematizing the singular category of the Human by questioning how the instantiation of the borders, boundaries and limits of what is 'Human' took place, and all of the abjections its reproduction continues to entail. Their approaches also offer a glimpse into the way we can politicise the bodies - living and dead - of women who struggle for alternatives to the conservative cycle taking hold of Latin America. ${ }^{14}$

Responding to a central issue of feminist scholarship in the 1970s, Haraway's approach to 'situated knowledges' called for a more responsible feminist practice, open to perspectivism and accountability. Her concern with a 'politics of location' questioned the 
ways through which bodies are materialised, i.e., how they become identifiable and able to speak with a voice, from a certain position. In the search for embodied and localisable knowledge claims, her approach called for an 'enunciative politics' (Hinton 2014), predicated on the ability of embodied subjects to speak from a certain position and take responsibility for their - necessarily partial - speech.

Appealing to the embodied nature of all vision, Haraway opened up the question of the power to see in feminist scholarship; rather than starting from a universal existence, feminist scholarship was called to respond for (partial) 'sightings,' not (total) 'beings', and for the responsibility of translating and forming solidarities among necessarily differential positions. According to her, 'the split and contradictory self is the one who can interrogate positionings, and be accountable, the one who can construct and join rational conversations and fantastic imaginings that change history' (Haraway 1991:193). No 'body' has a prerogative of a fixed identity - be it of sex, gender, race, class, nation - which makes it that much harder - or at least calls for more responsibility - to form attachments and produce individual and collective agency.

Butler's (1993) concept of 'performativity' further developed the importance of materiality for feminism. By disturbing the assumption of a dualism between sex and gender - essentialism and constructivism, matter and meaning, nature and culture - Butler tried to convey that materiality does not pre-exist the discourses about it, being rather an effect of power. The body, in her view, cannot be conflated with a natural object, a blank slate awaiting inscription and signification; rather, the process of materialisation of a body i.e., of a certain identity - is itself predicated on a series of abjections, refusals, disavowals that are always already constructed. By inquiring into the specific procedures through which matter and discourse have come to be seen as two entities existing separately, her approach to the performativity of gender calls attention to the citational inscription of every form of identity, which puts in check the very idea of a politics of identity. According to her,

[I]t is not enough to claim that human subjects are constructed, for the construction of the human is a differential operation that produces the more and the less 'human', the inhuman, the humanly unthinkable. These excluded sites come to bound the 'human' as its constitutive outside, and to haunt those boundaries as the persistent possibility of their disruption and rearticulation (Butler 1993: xvii).

Karen Barad (2011: 125) later expanded Butler's account of performativity to think how all bodies, not merely human bodies, come to matter through the world's performativity.' She offers the concept of 'iterative intra-activity' to understand how all 'phenomena' - living and non-living, human and non-human - exist always already in-relation, never as separate, bounded objects. She particularly calls attention to the way the Butlerian concept of performativity, when accounting exclusively for humans' interactions, leaves unquestioned the very division between nature and culture, human and nonhuman that ground conceptions of 'humanity' which are based on profound inhumanity. The 
uncritical acceptance of this division is problematic, as Barad points out, precisely because of the way it authorizes the 'killability' of all that is nonhuman.

Thus inquiring the materiality of other forms of non-human agency - of 'nature's queer performativity' - Barad's research opens up feminist scholarship to different kinds of questions: how 'things' (human/non-human; living/dead) get differentiated? Where and how boundaries are drawn, and how these boundaries materialise bodies - all bodies? What differentiates living and dead when we stop assuming that this boundary is always already there? For, as Barad (2011:125) claims, 'differentiating is not a relation of radical exteriority, but of agential separability, of exteriority-within.' In this sense, the 'women' in feminism cannot be defined in any essentialist way, leaving much space to inquire into the articulations between the live, the dead and the surviving bodies of women, and how they can materialise political resistance through their daily entanglements and solidarities.

Following Spivak's (2005) attempt to recover the representability of the subaltern, I will suggest in what remains of this article that women's bodies - their lives, deaths and survivals (Dauphinée and Masters 2007) - offer an important starting point for reconfiguring the political. As Dauphinée and Masters claim, despite the widespread work of death which goes on under - or as the flipside of - biopolitical regimes, the latter's main function remains to deny these deaths, for 'it is death that exposes the biopolitical project of sovereign power' (Dauphinée and Masters 2007: xiii). The reproduction of death by regimes whose main task is to produce life becomes, then, a matter of denying it, which means denying humanity to those killable bodies: 'you cannot kill that which is not constituted as "living"' (Dauphinée and Masters 2007: xiii). To pay attention to those killable bodies, to what constitutes their lives and deaths, as well as their survivals, becomes a way to unsettle the inner workings of such regimes.

\section{Can the body speak to the political?}

How does this emphasis on materiality help to account for the context of gendered violence in Latin America? My argument here is that this debate can open avenues to rethink agency and resistance in light of the new forms of expression and articulation that have been under way in the political sphere. Furtheremore, I claim that the contemporary forms that feminist resistance is taking in the region not only present new possibilities of articulation by using unprecedented technologies - such as the internet - but that they in fact are producing a new account of the political. Through the politicization of materiality - of feminized bodies, whether living, dead, or potentially killable - feminist resistance has been re-centering the question of gender and the political: it is no longer about bringing women to the heart of an already functioning political sphere, which already implicates a very specific gendered structure, in which the subject of speech must expunge the material and corporeal in search for the rational. Rather, contemporary feminist resistance has been demanding - and producing - a rearticulation of the political to account for the corporeal, the material, the situated, the epidermal - i.e. the racial, gendered, classed nature of all life. By doing so, this article raises the very urgent question of how this inscription 
of materiality can bring different forms of attachment to bear on the political, so as to recreate and re-signify its possibilities.

Segato's framework allowed me to understand different operations of gendered violence in the region, making sure that this violence always be understood through an intersectional prism. In stressing how gendered violence in Latin America is connected with markers of class and race, Segato joins a decolonial feminist perspective, which highlights the need to understand the coloniality of power, gender and being that continues to produce violence in Latin American societies, long after decolonization (Quijano 2000; Mignolo 2003; Maldonado-Torres 2007; Lugones 2010; Segato 2012). Also, her account produces an intricate analysis of how power operates in and through the materiality of bodies, which are rendered as territories to be taken and conquered in the search for retrieving sovereignty over the territory of the nation.

In the last part of this article, I make an effort to move from Segato's diagnosis of this operation of power to Spivak's concern with somehow retrieving the subaltern's voice and the possibility for agency where none seemed possible. While this move may be controversial considering their different traditions of thought, I believe their contributions can be mutually productive in building an account of resistance that carries the potential to re-signify the political. In this effort to bring them in conversation, I emphasise the way in which their reflections meet at the point in which they understand, first of all, that gender cannot be taken as a single marker of identity, and therefore refuse any form of simplistic or one-sided explanation of gender violence that does not account for the effects of colonialism and coloniality. What they offer, instead, is a complex analysis of how networks of power can create realms of (non-)existence where bodies are objectified, killed, rendered without agency - or made, in Spivak's famous formulation, voiceless (Spivak 1988).

While both authors provide fruitful insights into the ways gender is profoundly implicated in the workings of a necropolitical power which creates gendered zones of abjection, of non-being, Spivak's attempt to retrieve a space for agency by creating conditions for these (supposedly inert bodies) to speak back to the political offers me a particularly interesting way to theorize the activities of contemporary feminist collectives which refuse to let the dead bodies be only dead bodies and instead, try to create conditions in which they can speak.

Spivak defines subalternity as 'a position without identity' (2005: 476), and the subaltern as s/he who '[is] removed from all lines of social mobility' (Spivak 2005: 475). This definition points to the lack of agency which characterises the subaltern in her inability to speak and/or be heard (Spivak 1988). In this definition, Spivak is offering a view according to which agency and subalternity are opposed categories: whereas agency implies a certain institutional recognition of action, subalternity refers to the non-recognisable action. As she claims, 'subalternity is where social lines of mobility, being elsewhere, do not permit the formation of a recognisable basis of action' (Spivak 2005: 476).

Her controversial claim relies on the difference between the constative and the performative: relying on Marx's discussion of class consciousness, she stresses the way the (constative) economic conditions of existence of a class do not translate into its (performative) 
capacity for collective action. The question of political representation becomes crucial, then, precisely because of the inexistence of a primordial identity to be represented. How do you represent the other when this other occupies a position without identity? More particularly, if the subaltern cannot herself formulate/vocalise her interests - or even when she can, there is no institutional recognition of her voice - how does the feminist intellectual act without falling into ventriloquism - and therefore into the further concealment of the other's voice? This question becomes crucial to inquire into the condition of the female body in Latin America - a body that is obliged by all kinds of state and non -state apparatuses - the media, the family, the congress, the constitution - to remain silent (or inaudible) in the course of its own victimisation; and even more urgent when we think that this body may be a dead female body physically unable to speak.

In order to respond to these questions, Spivak argues that political representation must be thought about not as an operation taking place between two separate individuals, in which one represents the interests of the other. Her account of performativity requires, instead, metonymy: 'I put aside the surplus of my subjectivity and metonymise myself, count myself as the part by which I am connected to the particular predicament so that I can claim collectivity, and engage in action validated by that very collective' (Spivak 2005: 480 ). Only through the artificial construction of a 'we' that is not identitarian, but performative, can subaltern agency be recognised in the political arena. Because it is artificial, this construction can never be definitive or final, but localised and historical, built up on occasion, opening the public sphere to a cultivation of democratic behaviour.

If it is not to become a matter of 'speaking for' the other, then representation becomes an ethical stance towards the other, a responsibility to create an infrastructure in which subaltern agency can be recognised. Responsibility, as Spivak (cited in Kapoor 2004: 642) argues, is 'not so much a sense of being responsible for, but of being responsible to, before will.' This is an ethical position which offers no guarantees, and cannot be grounded on any legal certainty or all-encompassing reason. Rather, any possibility of responsibility depends on this uncertain crafting of collective agency. This uncertainty is affective once it involves the recognition of the insufficiency of reason alone to perform the political, and above all, an admission of complicity with the structures which keep the subaltern silent (or inaudible).

The feminist intellectual activist here is removed from any possibility of transparency before the political, and becomes responsible for this representation. Nothing qualifies her 'naturally' to speak as a woman, or for the women. Her metonymic political performance of collectivity involves a disposition to engage in a power play, to admit her privilege, her complicity with the structures of which she is part - and thus unlearn her privilege. Negating being part of such structures only reinforces the attempt to efface the subject from its position of authority, and therefore contributes to the projection of one's personal interests and positions into the other. As Kapoor (2004: 640) makes clear, 'you can never represent or act from an "outside," since you are always already situated inside discourse, culture, institutions, geopolitics.' Representation, then, involves an imperative to learn to learn from below: 'it is suspending my belief that I am indispensable, better, or culturally 
superior; it is refraining from always thinking that the Third World is "in trouble" and that I have the solutions; it is resisting the temptation of projecting myself or my world onto the Other' (Spivak, cited in Kapoor 2004: 641-2).

Spivak's reflections on the representability of the subaltern open an important avenue to think through the questions concerning materiality and embodiment in feminist scholarship. In particular, it offers a way to politicise not only the living bodies of women who daily struggle against male violence in profoundly gendered biopolitical regimes, but also to represent those dead bodies who have effectively fallen prey to the necropolitical underpinnings of those very regimes. By learning to learn from women's bodies, which means recognising that there is no position of identity to be achieved and, therefore, assuming responsibility before the other, we can begin to metonomise ourselves into new forms of attachments and performatic collectives. Building an 'infrastructure for agency' (Spivak 2005) dislocates the need for a politics based on identity and reclaims a space for representation which defies our traditional accounts of the political.

This seems to be precisely what is at stake into how women have been organizing themselves in Latin America. According to Palmeiro (2017a)

It is a mobilizing moment. We do not seat [sic] and wait: this mobilization happens in the body. It is a wonderful experiment of disobjectification. Collectively, we write and think together. It is an incredible experience, in which one goes out of oneself, of the ego, to enter a collective brain. The ideas transform and grow in a spectacular way, in a process of creation and collective transformation of subjectivity that exceeds the group. We are ceasing to be what we were and realizing what we are capable of doing. [...] We are taking power and releasing power, developing orselves [sic] as historical and revolutionary subjects in the world.

With the risk of overstating the achievements of articulations which are always historical and, therefore, must be comprehended as ongoing efforts to resist forms of power that are constantly shifting and rearticulating, I believe these discourses that are gaining traction in Latin American feminist activism and scholarship point to a very important moment to disrupt traditional accounts of the political. While I believe that this disruption is already under way, and is certainly uncontrollable in its effects and resignifications, I do not claim here that recent movements have found the way to defeat historically placed structures of power which sustain the funtioning of the political sphere. By mobilizing the crossed contributions of the feminist authors debated in the previous pages, with particular attention to Segato's and Spivak's conceptual apparatuses, I however find important entry points for grasping current transitions without recurring to a simplistic narrative of novelty. They provide conceptual tools to identify and think forms of political representation that do not need to be invented from scratch, as an intellectual gift to be put in motion by activists on the field; rather, they allow me to glimpse at articulations that are already under way in order to see their potential to recreate the political through different 
performances and attachments not easily recognizable within the traditional tools of political analysis and debate. Collectivelly, their accounts provide insights into not only how feminized bodies are affected by gendered violence, but most importantly, of how their materiality can be the very frame through which political resistance is already being reconstructed.

\section{Conclusion}

As the world made by men for men is collapsing because of its own contradictions, a new world is being dreamed of and created. We are up and coming. - Cecilia Palmeiro (2017b)

Cecilia Palmeiro's words point to the utopian character of recent feminist articulations throughout the world, and the particularly strong effect they are having in building feminist solidarities in Latin America. In order to fracture the crude reality of a modern politics which has been repellent to women - one created 'by men and for men', as she insightfully claims - it is necessary to think beyond the traditional languages and experiences which have served to dehumanise and thus exclude most of life - not only human life - from the political, and therefore, from democracy.

In this context, Spivak's project of representation seems to offer a productive insight into the way these new feminist attachments are being forged. When 'women' become able to establish a conversation across wide differences, turning previous grievances and differential identities into a resource for action, they seem to be exercising precisely the responsibility to represent the other to which Spivak alludes to - a responsibility which fractures the binarism between the universal and the particular, identity and difference, the one full Human and all of the multiple incomplete Others, and instead creates a space to think of how we are all accountable to one another. By representing the female body, contemporary feminist articulations retrieve the voice of those who have long been kept silent (or inaudible) by necropolitical structures of power. Internet and street protests have been stressing precisely this metonymic ability to craft collective agency out of singularity - irreducible difference - thus creating structures which allow for the revolutionary recognition of this other.

We have constituted ourselves as a revolutionary subject, yet our revolution cannot be captured in the traditional frames of representative democracy, although it appears and floods everywhere. The tide permeates artistic languages, intervenes in political parties, imposes agenda within trade unions, changes the relations of production in factories and in the informal economy, fuels disputes over power in all spheres of life. It blooms in the street protests and exploits in the households and in beds. This is an existential revolution, and we are organizing ourselves to change it all (Palmeiro 2017b). 
Of course, there is a long way for these movements and new articulations to bring about significant transformations to women's lives. After all, the conservative tide is still very strong in the region, and women continue to die at an outrageous pace. However, it seems that feminist articulations carry today's most powerful promise of constructing alternative spaces of political production and democratic ethos - alternative worlds. By working through materiality and embodiment and defying the laws which forbid the body from speaking back to the political, a transnational feminism begins to be articulated beyond the traditional boundaries which divided people among states, genders, races, ethnicities, classes. In doing so, it starts to create a new vocabulary, new forms of articulation and popular participation, opening spaces for different experiments in democracy. New technologies connect the bodies and transform them, as well as their ability to communicate to each other and build affective solidarities. As Palmeiro (2017a) remarks, it is an experiment, where we create theory and a new political practice, imagining a world where we want to live and coming together to see how we can get there'

\section{Notes}

1 A study from the Institute of High International Studies in Geneva, Switzerland, shows that Latin American countries account for more than half of the 25 countries with highest rates of homicide against women (BBC 2016). In Argentina, a study from the non-governmental organisation La Casa del Encuentro (n.d.) shows that 290 women were victims of femicide only in 2016, amounting to one woman being killed every 30 hours in Argentina - the second highest rate since 2008. Brazil, for its turn, accounts for the 5th highest femicide rate in the world, after El Salvador, Colombia, Guatemala and Russia, according to the Map of Violence 2015 (Waiselfisz 2015).

2 Of course, the image of a decline in the progressive political cycle in Latin America offers a rough, problematic formulation to a complex imbrication of multiple processes in course throughout the region. There are many layers in this 'cycle', continuities, discontinuities, and different logics - local, regional, and international - which must be understood so as to 'approach the complex set of mutations experienced in Latin America without yielding to the calls for order and normalisation that make invisible the networks of resistance present in the region's heterogeneous territory' (Gago and Sztulwark 2016: 606).

3 Lucía's case is only one in an abundant sea of femicides committed daily in Latin American countries. Her death by impalement occurred just a few days after the $31^{\text {st }}$ National Women's Meeting, which gathered an estimated 70,000 women in Rosario, Argentina, and was brutally repressed by the police (Ni Una Menos 2016, 2017b; Iricibar 2016; Palmeiro 2017a).

4 All excerpts originally published in Spanish or Portuguese were freely translated to English by the author.

5 According to Pomeraniec (2015), in the hours that followed the march, 'Supreme court justice Elena Highton announced a registry of femicides would be set up at the court. The office of President Cristina Fernández de Kirchner set off a series of tweets emphasising her government's concern. Meanwhile, the government's Human Rights Secretariat announced it, too, would start to compile statistics on femicides.'

6 The movement was inspired by the 1975 Women's Strike in Iceland, where 90\% of women refused to perform their paid and unpaid tasks in the workplace and in their daily reproductive activities in order to protest against sexual harassment and demand equal wages. More recent forms of inspiration for this Strike were the 2016 Polish Women's Strike to stop a bill from banning abortion, and of course the 2016 Argentinian march against femicide and male violence (Arruzza and Bhattacharya 2017b).

7 According to Segato, 'We attempted this in the 1970s by saying "the personal is political," the era's feminist slogan, which since then has led to struggles over laws and public policies without much success except for on paper. Perhaps this is because it was not the best idea, as Foucault noted early on, to struggle for a life under the panopticon's eye or to invite the courts into the bedroom, as became usual in North America. 
Perhaps, then, such a path was neither the most interesting nor the wisest, since gender's violent and expropriating structure did not recede anywhere' (Segato 2016: 618).

8 In Brazil, data from the Ministry of Health show an alarming increase in the number of gang rapes, from 1,570 in 2011 to 3,526 in 2016, pointing to an average of 10 cases per day. This number represents only $15 \%$ of the reported cases of rape, and which still falls short of the reality, since not all victims go to hospitals or the police. In fact, a study by the Institute for Applied Economic Research (IPEA) shows that only $10 \%$ of the cases are reported, amounting to an astounding estimate of 450,000 unreported cases (Collucci 2017). For more information on the case of gang rapes in Latin America see Gordon (2017).

9 In Brazil, a protest by right-wing organizations against Judith Butler's presence in the country emphasized the opposition against what is called a 'gender ideology' that threatens the family, traditions and society. The attacks involved internet manifestations and physical harassment during the event she was attending a Colloquium about Democracy which had little to do with her work on gender. A protest at the venue of the event involved the symbolic act of burning an effigy of Butler portrayed as a witch; and a small group of people protested in the airport when she was leaving, calling Butler a pedophile. See Jaschik (2017); Sexuality Policy Watch (2017). Attacks on the discussion over gender have also impacted the educational plans in different Latin American countries and led to the boycott against institutions, businesses, artists, and intellectuals who promote sexual diversity. For instance, the Peruvian Supreme Court removed the emphasis on gender equality from Peru's 2017 school curriculum, leading to the withdrawal of textbooks that had already been distributed to more than 11,000 schools throughout the country. And in Brazil, pressure on the Congress led to the prohibition of teaching gender and sexuality in the National Education Plan (Pina 2017).

10 A growth in conservative measures towards abortion has become a recent trend in the region as well. In Brazil, an amendment to the constitution is being debated by the Congress to criminalize abortion in all cases, including those that are covered by the Constitution today. See Human Rights Watch (2017); Langlois (2017). Data from the Guttmacher Institute (2017) show the state of abortion rights in Latin America and the Caribbean: according to this study, more than $97 \%$ of women in the region live in countries where abortion is restricted, or banned altogether (seven countries ban abortion including in cases in which the mother's life is at risk). In the meanwhile, in 2014, unsafe abortions were responsible for $10 \%$ of maternal deaths.

11 Data from the Pan American Health Organization (2012: 3) show that in Latin America the number of non-intimate homicides is particularly high and on the rise. For more detailed information on the state of violence against women in Latin America, see: Pan American Health Organization $(2012,2015)$.

12 According to Segato (2016: 620), 'there have never been more protective laws for women's rights, training sessions for security forces, more published literature in circulation about women's rights, more prizes and recognitions for accomplishments in the field of women's rights, and yet we women continue dying. Our bodies were never before so vulnerable to lethal aggression at home, and torture until death never existed as it does in contemporary informal wars. Our bodies never received more medical intervention seeking the shape of compulsory happiness or beauty, and we were never surveilled so closely regarding abortion as we are now.'

13 This doubled emphasis, on the one hand, on the irreducible materiality of sex as a mark of differential experiences, and on the other, on the need to struggle for equality before the law, has brought a paradox to bear at the heart of feminist scholarship. According to Thiele (2014:10), 'the paradox here is that feminism's major claim for (sexual) difference(s) is, on the one hand, a rejection of determinist and essentialist understandings of sex/gender and a demand for equality and equal access, yet this demand can, on the other hand, only ever be brought about by emphasizing precisely the specificity of (sexual) difference(s).' For a discussion of this 'equality vs. difference' paradox see Thiele (2014).

14 By saying that, a clarification is in order: first, arguing that 'we' can politicise women's bodies does not presuppose any pre-defined 'we' which stands fully formed and begins a process of authorization of what is or is not political, and of who can or cannot enter this reality; rather, I understand the 'political' as itself materialising - and therefore transforming - the 'we' and the 'bodies of women.' Following Barad (2011), I understand all of these phenomena to be inseparable ontological entanglements that intra-act to materialise reality. 


\section{References}

Aguilera, Meztli Yoalli Rodríguez. 2017. 'Gendered Necropolitics: On the Politics of Death Against Women in Mexico.' Latinx Spaces [online], 25 July. At http://www.latinxspaces.com/gendered-necropolitics-the-politics-of-death-against-women-in-mexico [Accessed on 30 January 2018].

Alcoff, Linda Martín, Cinzia Arruzza, Thiti Bhattacharya, Nancy Fraser, Barbara Ransby, KeeangaYamahtta Taylor, Rasmea Yousef Odeh and Angela Davis. 2017. 'Women of America: we're going on strike. Join us so Trump will see our power.' The Guardian [online], 6 February. At https://www. theguardian.com/commentisfree/2017/feb/06/women-strike-trump-resistance-power [Accessed on 7 February 2018].

Arruzza, Cinzia and Tithi Bhattacharya. 2017a. 'Strikes were a part of Women's Day before. With Trump, they will be again.' The Guardian [online], 21 February. At https://www.theguardian.com/ commentisfree/2017/feb/21/womens-day-strike-march-8-donald-trump [Accessed on 7 February 2018].

2017b. 'What the Women's Strike Means.' Jacobin [online], 2 March. At https://www.jacobinmag.com/2017/03/international-womens-strike-march-8-capitalism/ [Accessed on 14 February 2018].

Barad, Karen. 2011. 'Nature's Queer Performativity' Qui Parle 19 (2): 121-158.

BBC [online]. 2016. País por país: o mapa que mostra os trágicos números dos feminicídios na America Latina. 6 December. At http://www.bbc.com/portuguese/internacional-38076091 [Accessed on 14 February 2018].

Butler, Judith. 1993. Bodies that Matter: On the Discursive Limits of Sex. London/New York: Routledge.

Cartolano, Fernanda. 2016. 'El país de las mujeres.' Agencia Universitária de Notícias [online], 21 October. At https://www.auno.org.ar/article/el-pais-de-las-mujeres/ [Accessed on 5 February 2018].

Collucci, Claudia. 2017. 'País registra 10 estupros coletivos por dia; notificações dobram em 5 anos.' Folha de São Paulo [online], 20 August. At http://www1.folha.uol.com.br/cotidiano/2017/08/1911346-pais-registra-10-estupros-coletivos-por-dia-notificacoes-dobram-em-5-anos.shtml [Accessed on 14 February 2018].

Conway, Janet. 2012. Transnational Feminisms Building Anti-Globalization Solidarities. Globalizations 9 (3): 379-393

2018. When food becomes a feminist issue: popular feminism and subaltern agency in the World March of Women. International Feminist Journal of Politics 20 (2): 188-203

Dauphinée, Elizabeth and Cristina Masters (eds). 2007. The Logics of Biopower and the War on Terror: Living, Dying, Surviving. New York: Palgrave Macmillan

Foucault, Michel. 2000. 'The Subject and Power. In James D. Faubion (ed) Power. London: Penguin Books, pp. 208-226.

. 2008. The Birth of Biopolitics: Lectures at the Collège de France, 1978-79. New York: Palgrave Macmillan.

Gago, Verónica and Diego Sztulwark. 2016. 'The Temporality of Social Struggle at the End of the "Progressive” Cycle in Latin America.' The South Atlantic Quarterly 115 (3): 606-614. 
Goñi, Uki. 2016. 'Argentina: hundreds of thousands of women set to protest against violence.' The Guardian [online], 19 October. At https://www.theguardian.com/world/2016/oct/19/argentinawomen-strike-violence-protest [Accessed on 5 February 2018].

Gordon, Sarah. 2016. 'NiUnaMenos: How the brutal gang rape and murder of a schoolgirl united the furious women of Latin America.' The Telegraph [online], 21 October. At http:// www.telegraph.co.uk/women/life/niunamenos-how-a-schoolgirls-brutal-gang-rape-and-murderunited/ [Accessed on 16 February 2018].

Guttmacher Institute [online]. 2017. Abortion in Latin America and the Caribbean. September. At https://www.guttmacher.org/fact-sheet/abortion-latin-america-and-caribbean [Accesssed on 16 February 2018]

Haraway, Donna. 1991. 'Situated Knowledges: the science question in feminism and the privilege of partial perspective.' In Donna Haraway. Simians, Cyborgs and Women: The Reinvention of Nature. New York: Routledge, pp. 183-202

Hinton, Peta. 2014. "Situated Knowledges" and New Materialism(s): Rethinking a Politics of Location. Women: A Cultural Review 25 (1): 99-113.

Human Rights Watch [online]. 2017. Brazil: Reject Abortion Ban. 12 December. At https://www.hrw. org/news/2017/12/12/brazil-reject-abortion-ban [Accessed on 14 February 2018].

Infobae [online]. 2016. Miércoles negro: miles de personas marcharon en todo el país contra los femicidios. 19 October. At https://www.infobae.com/sociedad/2016/10/19/comienzan-las-marchas-contra-los-femicidios-en-todo-el-pais/ [Accessed on 7 February 2018].

Iricibar, Valentina. 'Police Unleash Violent Repression On Women's Rights Activists In Rosario.' The Bubble [online], 10 October. At http://www.thebubble.com/police-unleash-violent-repression-onwomens-rights-activists-in-rosario/ [Accessed on 16 February 2018].

Jaschik, Scott. 2017. 'Judith Butler on Being Attacked in Brazil.' Inside Higher Ed [online], 13 November. At https://www.insidehighered.com/news/2017/11/13/judith-butler-discusses-being-burned-effigy-and-protested-brazil [Accessed on 14 February 2018].

Kapoor, Ilan. 2004. 'Hyper-self-reflexive development? Spivak on representing the Third World 'Other." Third World Quarterly 25 (4): 627-647.

La Casa Del Encuentro [online]. n.d. Femicidios. At http://www.lacasadelencuentro.org/femicidios. html [Accessed on 18 February 2018].

Langlois, Jill. 2017. 'In a rare court challenge to its abortion ban, Brazil grapples with its own version of Roe vs. Wade.' Los Angeles Times [online], 8 December. At http://www.latimes.com/world/la-fgbrazil-illegal-abortions-2017-story.html [Accessed on 14 February 2018].

Lugones, María. 2010. 'Toward a decolonial feminism.' Hypatia 25 (4): 742-759.

Maldonado-Torres, Nelson. 2007. On The Coloniality Of Being: Contributions to the development of a concept. Cultural Studies 21 (2-3): 240-270.

Mbembe, Achille. 2003. 'Necropolitics.' Public Culture 15 (1): 11-40.

Mignolo, Walter. 2003. The Darker Side of the Renaissance: Literacy, Territoriality, and Colonization. 2nd ed. Ann Arbor: The University of Michigan Press.

Nandy, Ashis. 1983. The Intimate Enemy: Loss and Recovery of the Self under Colonialism. Delhi: Oxford University Press. 
Ni Una Menos. 2016. 'Nosotras Paramos.' Facebook [online], 20 October. At https://www.facebook. com/notes/ni-una-menos/nosotras-paramos/544964935694693 [Accessed on 7 February 2018].

2017a. 'Llamamiento al Paro Internacional de Mujeres - 8 de marzo 2017.' Facebook [online], 23 January. At https://www.facebook.com/notes/ni-una-menos/llamamiento-al-paro-internacional-de-mujeres-8-de-marzo-2017/588055324718987 [Accessed on 5 January 2018].

2017b. 'How Was the March 8 International Women's Strike Woven Together?' Viewpoint Magazine [online], 16 February. At https:/www.viewpointmag.com/2017/02/16/how-was-themarch-8-international-womens-strike-woven-together/ [Accessed on 7 February 2018].

Palmeiro, Cecilia. 2017a. 'A violência econômica é feminicida, afirma ativista do Ni Una Menos. Interview by Paula Guimarães.' Catarinas [online], 6 March. At http://catarinas.info/violencia-economica-e-feminicida-afirma-ativista-do-ni-una-menos/ [Accessed on 16 February 2018].

2017b. 'A Women's Strike Organizer on Feminism for the 99 Percent: Interview by Linda Young.' Broadly [online], 11 December. At https://broadly.vice.com/en_us/article/3kpk53/-womensstrike-organizer-cecilia-palmeiro-feminism-for-the-99-percent [Accessed on 16 February 2018].

Peterson, V Spike (ed). 1992. Gendered States: Feminist (Re)visions of International Relations Theory. Boulder: Lynne Rienner.

Pina, Rute. 2017. 'Do México ao Uruguai, campanha contra "ideologia de gênero" mobiliza conservadores.' Brasil de Fato [online], 29 November. At https://www.brasildefato.com.br/2017/11/29/ do-mexico-ao-uruguai-campanha-contra-ideologia-de-genero-mobiliza-conservadores/ [Accessed on 14 February 2018].

Pomeraniec, Hinde. 2015. 'How Argentina rose up against the murder of women.' The Guardian [online], 8 June. At https://www.theguardian.com/lifeandstyle/2015/jun/08/argentina-murderwomen-gender-violence-protest [Accessed on 5 February 2018].

Quijano, Anibal. 2000. Coloniality of Power, Eurocentrism and Latina America. Nepantla: Views from South 1 (3): 533-580.

Segato, Rita Laura. 2012. 'Gênero e colonialidade: em busca de chaves de leitura e de um vocabulário estratégico descolonial.' E-cadernos ces [online] 18: 106-131. At https://journals.openedition.org/ eces/1533 [Accessed on 29 October 2018]

.2014a. Las nuevas formas de la guerra y el cuerpo de las mujeres. Puebla: Pez en el árbol.

. 2014b. 'Mujer y cuerpo bajo control.' Clarín Revista N. At https://www.clarin.com/ideas/ rita-segato-mujer-cuerpo-control_0_S1cTT1iDQg.html [Accessed on 1 February 2018].

. 2016. 'Patriarchy from Margin to Center: Discipline, Territoriality, and Cruelty in the Apocalyptic Phase of Capital.' The South Atlantic Quarterly 115 (3): 615-624.

Sexuality Policy Watch [online]. 2018. Judith Butler attacked in Brazil: a briefing. 11 January. At http://sxpolitics.org/judith-butler-in-brazil-a-briefing/17916 [Accessed on 14 February 2018].

Spivak, Gayatri C. 1988. 'Can the subaltern speak?' In Cary Nelson and Lawrence Grossbery (eds). Marxism and the Interpretation of Culture. Urbana: University of Illinois, pp. 271-313.

2005. 'Scattered speculations on the subaltern and the popular.' Postcolonial Studies 8 (4): 475-486.

Thiele, Kathrin. 2014. 'Pushing Dualisms and Differences: From 'Equality versus Difference' to 'Nonmimetic Sharing' and 'Staying with the Trouble.' Women: A Cultural Review 25 (1): 9-26. 
Topping, Alexandra and Molly Redden. 2017. "We are international, we are everywhere': women unite in global strike.' The Guardian [online], 7 March. At https://www.theguardian.com/world/2017/ mar/08/international-womens-day-political-global-strike [Accessed on 7 February 2018].

Vinte minutos [online]. 2016. "Miércoles negro' por los feminicidios tras el asesinato de la joven argentina.' 19 October. At https://www.20minutos.es/noticia/2866263/0/niunamenos-feminicidioslatinoamerica-lucia-perez-argentina-peru-chile-mexico/\#xtor=AD-15\&xts=467263 [Accessed on 7 February 2018].

Waiselfisz, Julio Jacobo. 2015. Mapa da Violência 2015: Homicídio de mulheres no Brasil. Brasília: Flacso Brasil. At http://www.mapadaviolencia.org.br/pdf2015/MapaViolencia_2015_mulheres.pdf [Accessed on 7 February 2018].

Pan American Health Organization [online]. 2012. Understanding and addressing violence against women: Femicide. Geneva: WHO. At http://apps.who.int/iris/bitstream/10665/77421/1/WHO_ RHR_12.38_eng.pdf [Accessed on 7 February 2018].

2015. Violence against Women: Strategy and Plan of Action on Strengthening the Health System to Address Violence against Women. At http://www.paho.org/hq/index.php?option=com docman\&task=doc_view\&Itemid=270\&gid=32433\&lang=en [Accessed on 18 January 2018].

Wright, Melissa W. 2011. 'Necropolitics, Narcopolitics, and Femicide: Gendered Violence on the Mexico-U.S. Border.' Signs 36 (3): 707-731.

\section{About the Author}

Natália Maria Félix de Souza is Professor at the International Relations Department of the Pontifical Catholic University of São Paulo (PUC-SP), and holds a PhD from IRI/ PUC-Rio, in which she engaged the limits of critique in international relations theory. Her work focuses mainly on critical approaches to subjectivity and subject formation, including feminist, post-structural, postcolonial and posthuman theories, and on decolonial approaches to knowledge and knowledge production. She is currently engaged in a number of initiatives regarding Gender, Sexuality and Women's Studies, including: co-editing the Conversations Section of the International Feminist Journal of Politics; co-editing a Portuguese-language book on 'Feminism, Gender and International Relations'; and advancing the agenda of MulheRIs in Brazilian IR. 


\section{Quando o Corpo Fala (a)o Político: Ativismo Feminista na América Latina e a Busca por Futuros Democráticos Alternativos}

Resumo: $\mathrm{O}$ artigo argumenta que os movimentos feministas emergentes no contexto das lutas políticas contemporâneas da América Latina - como Ni Una Menos - permitem uma reconceituação do político, junto com seus sujeitos e objetos. A singularidade desses movimentos se baseia na maneira como eles conseguiram vincular os assassinatos comuns dos corpos das mulheres às extraordinárias alianças entre diferentes movimentos sociais. Uma inspeção mais minuciosa dessas experiências contínuas que mobilizam diferentes arenas rizomáticas de enredos políticos - como a internet e as ruas - nos permite ver como os apegos e movimentos feministas latino-americanos podem redefinir as práticas democráticas e construir diferentes formas de comunidade. Ao resistir ao que é percebido como 'uma guerra contra as mulheres na América Latina', esses movimentos permitem compreender o funcionamento de uma necropolítica de gênero, que liga a morte das mulheres ao funcionamento da política moderna e das subjetividades modernas. Ao fazê-lo, eles politizam não apenas as vidas (e, portanto, as vozes) das mulheres que lutam no/ para o político, mas também as mortes (e, portanto, os silêncios) sobre os quais o político foi construído. Além disso, ao politizar o papel do corpo na arena política e ética, esses movimentos abrem nossos imaginários políticos às possibilidades de novos apegos, filiações e articulações que não são subsumidos sob categorias e valores universais abstratos, nem limitados a identitários e, portanto, legalistas. afirmações do político. Seguindo esses argumentos, defendo que as articulações feministas contemporâneas na América Latina contestam de forma produtiva a validade do 'humano' 'abstrato', universal e moderno para pensarmos futuros políticos alternativos. Ao politizar a materialidade e a corporificação juntamente com a linguagem e o discurso como produtivos de ontologias políticas, as feministas abrem o espaço para reivindicar a função política do corpo feminino.

Palavras-chave: América Latina; corpo; feminismo; política democrática; resistência política; feminicídio.

Received on 18 February 2018, and approved for publication on 5 November 2018.

\section{(cC) BY-NC} https://creativecommons.org/licenses/by-nc/4.0/ 
